\title{
Recent Trends in Temperature and Relative Humidity in Bawku East, Northern Ghana
}

\author{
Frimpong, K. ${ }^{1}$, Oosthuizen J. ${ }^{2} \&$ Van Etten E. J. ${ }^{1}$ \\ ${ }^{1}$ School of Natural Science, Edith Cowan University, Perth, Western Australia \\ ${ }^{2}$ School Exercise and Health Sciences, Edith Cowan University, Perth, Western Australia \\ Correspondence: Frimpong, K., School of Natural Science, Edith Cowan University, Perth, Western Australia. \\ Tel: 61-40-502-6844. E-mail: frimpongk@hotmail.com
}

\author{
Received: March 5, 2014 Accepted: March 24, 2014 Online Published: April 23, 2014 \\ doi:10.5539/jgg.v6n2p69 URL: http://dx.doi.org/10.5539/jgg.v6n2p69
}

\begin{abstract}
Extensive analyses of trends in mean annual and mean seasonal minimum and maximum temperatures and relative humidity were examined for Bawku East, northern Ghana, for the period 1961 to 2012. Mean monthly maximum and minimum temperatures were used to analyse and establish recent temperature trends on an annual and seasonal basis. The year was divided into rainy and dry seasons for the seasonal trends. Mean monthly relative humidity at 6 am and 3 pm from 1961 to 2012 were considered to show recent trends in humidity since temperature and humidity interact to determine the heat exposure for outdoor workers. Regression analysis was used to illustrate trends and calculate mean yearly and seasonal rate of change. A Durbin-Watson statistical test was employed to verify autocorrelation of the residuals of the trend models and none was detected. Results showed a gradual and statistically significant rise in both mean minimum and mean maximum temperatures at two stations (Manga and Garu). There was an inconsistent pattern of trend observed at the third station (Binduri). Declining trends in relative humidity were observed at 6 am and $3 \mathrm{pm}$ at seasonal and annual levels at Binduri and Garu, while there was a rising trend in relative humidity at Manga. The importance of this study hinges on the linkage between heat exposure (temperature and air humidity) and human health in the wake of climate change on outdoor farmers in developing countries who spend many hours doing manual work in the heat. On the whole, the rising temperature has impacted on ecosystem services in the study area.
\end{abstract}

\section{Introduction}

The Fourth Assessment Report of the Intergovernmental Panel on Climate Change (IPCC) revealed an increasing trend in global average temperature since 1850 and recognised that 11 of the last 12 years (1995-2006) before the publication of the report were ranked among the warmest years on instrumental record (Christensen et al., 2007; Jones et al., 2007; Pachauri, 2007; Trenberth et al., 2007). Global mean temperature was recognized to have increased by $0.76^{\circ} \mathrm{C}$ within the period of 1850 to 2005 . Depending on global action to reduce greenhouse gas emissions, a predicted further rise in temperature of $1-5{ }^{\circ} \mathrm{C}$ within and beyond this century is envisaged (Jones et al., 2007). The IPCC noted that the predicted increase in average global temperature was highly likely due to emissions of anthropogenic greenhouse gases (Hegerl et al., 2007). In most parts of the world, both minimum and maximum temperatures have increased with significant positive trends beyond that predicted to be caused by natural variability (Brown, Caesar, \& Ferro, 2008). The regional projections of IPCC indicated that the West African region is likely to sustain a $3-4{ }^{\circ} \mathrm{C}$ increase in temperature over the period $1900-2100$. Within this region a $3^{\circ} \mathrm{C}$ rise is predicted to occur in the coastal and equatorial areas, while the western Saharan region is predicted to experience an increase of $4{ }^{\circ} \mathrm{C}$ (Christensen et al., 2007). The warming trend of temperature in Africa is perceived to be likely responsible for the increased dryness of the Sahel (Hulme, 1996). Temperature affects evaporation and availability of water (Glantz, 1992), and regulates physiological processes in humans (Parsons, 2003), animals and crops (Collins, 2011), so rises in temperatures are likely to have wide-ranging impacts.

Many studies on recent temperature trends have been carried out (Arora, Goel, \& Singh, 2005; Cane et al., 1997; Kruger \& Shongwe, 2004; Vose, Easterling, \& Gleason, 2005). The increasing trend of both minimum and maximum temperatures and decrease in the range of diurnal temperature in South Africa was demonstrated using meteorological data from 1951 to 1991 (Karl et al., 1993). However, studies of recent trends in temperature at 
more local scales are also needed given the fact that broad-scale analyses may mask considerable spatial and temporal variation in climatic trends. For instance data from 26 meteorological stations throughout South Africa showed different trends in mean annual temperatures across the country within the time frame of 1960 to 2003 (Kruger \& Shongwe, 2004). Inland stations showed significant and positive rises in mean maximum temperatures in line with global and national trends, while several coastal stations did not show such significantly positive trends (Kruger \& Shongwe, 2004). They also showed that temperature trends differed across seasons of the year (e.g., much greater rises in autumn compared to spring). An analysis of the recent climatic changes in one locality in South Africa (West Bank in East London) for the period 1975-2011 found significant increasing trends in both maximum and minimum annual temperatures, although temperature trends for particular months and seasons were not significant (Kalumba et al., 2013).

The levels of ambient air temperature and humidity are fundamental in assessing environmental heat stress on the health of a given population, especially in the tropics of developing countries where there are larger numbers of outdoor occupations (Byass, Twine, Collinson, Tollman, \& Kjellstrom, 2010). In the Bawku East of northern Ghana it is estimated that $65 \%$ of the population are engaged in agriculture (Ministry of Agriculture, 2012). In the wake of climate change, the combined effect of heat and humidity is becoming more stressful to outdoor workers (Sherwood \& Huber, 2010), and Bawku East is projected to experience an increase in temperature of $2.5-3{ }^{\circ} \mathrm{C}$ by the year 2020 (EPA, 2007). This makes it imperative to assess recent trends of temperature and humidity in this area in order to develop an appropriate community response to increases in temperature and heat exposure; the issue is further compounded by the fact that this region is among the poorest in Ghana with subsistent farming being the major occupation (Webber, 1996; Whitehead, 2006). Even though this study focuses on temperature trends and heat exposure on farmers' health, it is also worth mentioning that the effects of temperature on water content of the soil impacts on plant growth, especially at the early stage when the seeds are germinating (Helms, Deckard, Goos, \& Enz, 1996). The rate of drought occurrence is linked with temperature variation (Arora et al., 2005). Thus sustainability of subsistence farming may be jeopardized with the emergence of changing climate and an upsurge in temperatures. For policy purposes, it is important to ensure enough farmers remain engaged in the production of food crops to alleviate food insecurity associated with this area. Assessment of recent climatic trends can contribute to risk assessments and evaluation of impacts associated with climate change.

In this study, data from three meteorological stations were used to analyze trends in mean annual and mean seasonal temperatures and relative humidity between 1961 and 2012 for the localities within Binduri, Manga and Garu in Bawku East. The specific objectives of this study were to establish trends in mean annual maximum and minimum temperatures and in mean annual relative humidity (for both morning and afternoon), as well as trends in seasonal mean temperatures and relative humidity. In excessively humid environments, the evaporation rate of sweat is compromised, which in turn leads to an increase in core body temperature (Kjellström, 2009; Parsons, 2003). In view of this, temperature and relative humidity are key parameters in determining heat exposures of outdoor workers. In Bawku East, a large proportion of the workers are engaged in outdoor farming where workers spend approximately 8 hours a day cultivating vegetables, cereals and legumes in direct sun. The area is renowned for being very hot (McSweeney, 2012), so that any increase in temperatures is likely to have a serious impact on people's capacity to work outdoors. The high levels of poverty in this area (Webber, 1996; Whitehead, 2006) are also likely to increase if proper heat adaptation strategies are not implemented as it is likely to also become an issue of food insecurity if farm output is impacted.

Rainfall and temperature trends for the Ejura-Sekyedumase district of Ashanti, southern Ghana, showed a slightly decreasing pattern of rain and increasing in mean annual temperature. The central aim of their study was to relate perceptions of farmers about climate change to their degree of potential adaptation; however the authors did not consider the influence of relative humidity in their analysis and the study was conducted in a different climate zone compared to this study. Many studies exploring recent climate changes at local (Appiah, 2014; Fosu-Mensah, Vlek, \& MacCarthy, 2012) and continental scales (Cane et al., 1997; Easterling et al., 1997; Pascual, Ahumada, Chaves, Rodo, \& Bouma, 2006; Shrestha, Wake, Mayewski, \& Dibb, 1999) also did not factor in relative humidity and its implications for increased heat stress as a component of climate change. This current study is therefore unique in that it was conducted in a previously neglected part of Ghana and considered the impact of humidity on the heat experience of farmers.

\section{Setting of the Study}

Bawku East lies between latitudes $11^{\circ} 11^{\prime}$ and $10^{\circ} 50^{\prime}$ north and longitudes $0^{\circ} 18^{\prime}$ west and $0^{\circ} 61^{\prime}$ east in the north-eastern part of the upper east of Northern Ghana (Ministry of Food and Agriculture, 2014) (Figure 1). The area has only one annual period of rainfall with a prolonged dry season. Rainfall starts in June and ends in 
October. The dry season is associated with hot, dry and dusty harmattan winds. Temperatures in the dry season range from $14{ }^{\circ} \mathrm{C}$ at night to temperatures that frequently exceed $37{ }^{\circ} \mathrm{C}$ and in the day. The average annual rainfall ranges from $800 \mathrm{~mm}$ to $850 \mathrm{~mm}$ (Government of Ghana Offial Porter, 2014; Ministry of Food and Agriculture, 2014). The area is one of the poorest regions in Ghana characterized by a lack social amenities, inadequate social infrastructure, and harsh climatic condition (Laube, Schraven, \& Awo, 2011).

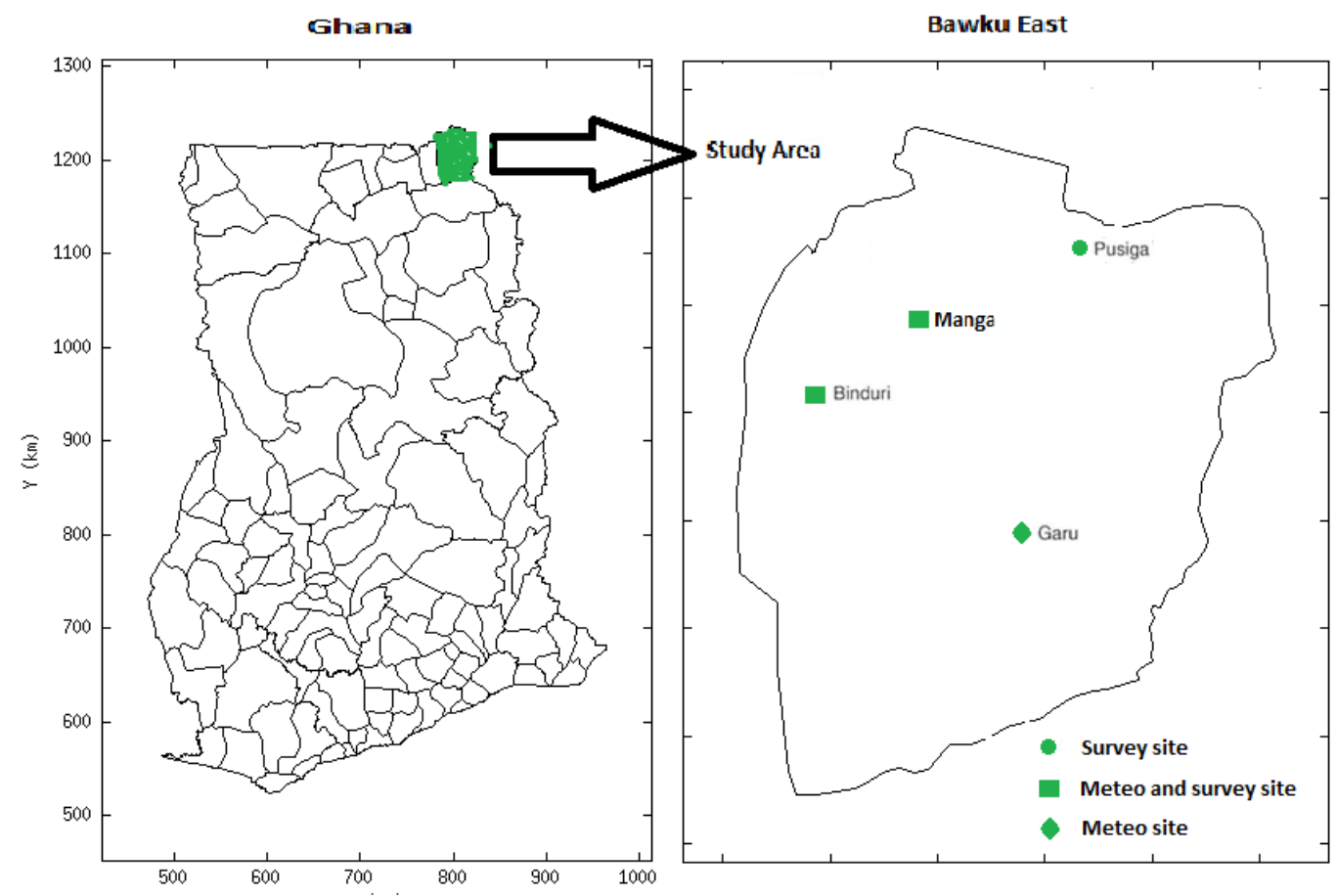

Figure 1. Map of Ghana showing Manga, Binduri and Garu (locations of meteorological stations)

\section{Data and Methodology}

In this study, data from three meteorological stations (Binduri, Manga and Garu) located in the Bawku East of northern Ghana (Figure 1) were used to analyze trends in mean annual and mean seasonal temperature and relative humidity between 1961 to 2012. These meteorological stations are located in the rural vicinity. Table 1 shows the location and coordinates of the meteorological stations.

Table1. The locations of the three meteorological stations in Bawku East of Northern Ghana (Anayah \& Kaluarachchi, 2009)

\begin{tabular}{lccc}
\hline Station & Latitude $^{\circ}$ & Longitude $^{\circ}$ & Elevation in metres (m) \\
\hline Manga & 11.02 & -0.27 & 231 \\
Garu & 10.85 & -0.18 & 236 \\
Binduri & 10.97 & -0.32 & 202 \\
\hline
\end{tabular}

The Ghana Meteorological Agency provided the data for the study. Monthly averages of minimum and maximum temperature and relative humidity were obtained from the three meteorological stations. The data covers the period 1961 to 2012, though some years within this time frame were not available due to unexplained reasons from the meteorological service agency. The earliest available data started from 1961 (Manga), whereas the data from the other two stations started in 1976. Yearly mean temperatures were calculated from the monthly mean temperatures. Similarly, mean monthly humidity was used to calculate mean annual relative humidity at both 6 am and $3 \mathrm{pm}$. The data for the study was compiled and quality controlled by the meteorological agency in Accra, Ghana. The missing data were extrapolated to create continuity of the trend. The extrapolation was done using the previous data next to a gap and the data immediately after a gap to estimate the missing data. 
The temperature and relative humidity data were further divided into seasons to depict the seasonal patterns in Bawku East of Northern Ghana. These were June to October for the rainy season and November to May for the dry season. Both mean yearly and mean seasonal trends of minimum and maximum temperatures and relative humidity at $6 \mathrm{am}$ in the dry and rainy seasons and at $3 \mathrm{pm}$ in the dry and rainy seasons were determined.

The data were plotted for each available year to illustrate temporal trends and analysed using linear regression to determine average rate of change in yearly mean minimum and maximum temperatures and change in yearly mean relative humidity at 6 am and $3 \mathrm{pm}$. This method is used by many researchers in the analysis of temperature and other atmospheric data for identifying trends (Kruger \& Shongwe, 2004; Mote, 2003). The Durbin-Watson test was used to verify autocorrelation of the residuals of the trend models; it was found that there was no auto-correlation.

\section{Results}

\subsection{Annual Trends in Temperature and Relative Humidity}

There was a significant rising trend $(p<0.001)$ in a mean yearly minimum temperature in Manga, as shown in Figure 1, with a slope of $0.029^{\circ} \mathrm{C}$ and a decadal change of $0.29^{\circ} \mathrm{C}$. Garu also showed a significant rising trend $(\mathrm{p}<0.001)$ in the mean annual minimum temperature with a slope of $0.042{ }^{\circ} \mathrm{C}$ and a decadal increase of $0.42{ }^{\circ} \mathrm{C}$ (Figure 6; Table 4). Binduri showed a different pattern with no significant rising trend in mean minimum yearly temperature and a slope of only $0.003{ }^{\circ} \mathrm{C}$, which translate to a mean decadal increase of $0.03{ }^{\circ} \mathrm{C}$ (Figure 4). In terms of mean yearly maximum temperature, Manga had a significant rising trend (Figure 2, Table 2) with a slope of $0.022{ }^{\circ} \mathrm{C}$ and a decadal increase of $0.22{ }^{\circ} \mathrm{C}$. A dissimilar trend in Binduri was found in mean yearly maximum temperature. However, between 2006 and 2010, there was a rising trend which sharply declined by the end of 2010 (Figure 4). The slope for Binduri was $0.021^{\circ} \mathrm{C}$ with a decadal increase of $0.21^{\circ} \mathrm{C}$. Garu had a rising trend in average annual maximum temperature, as shown in Figure 6, with a slope of $0.060{ }^{\circ} \mathrm{C}$ and a decadal increase of $0.60{ }^{\circ} \mathrm{C}$. Mean minimum temperature in Garu showed a rising trend with a slope of $0.042{ }^{\circ} \mathrm{C}$ and a decadal increase of $0.42^{\circ} \mathrm{C}$.

In terms of mean annual relative humidity at 6 am, data from Manga showed an irregular pattern with no clear rising or falling trend (Figure 3). In Binduri, as illustrated in Figure 5, there was a declining trend in morning humidity with a sharp upsurge in 2008. Garu showed a decreasing falling trend in mean relative humidity at 6 am. At $3 \mathrm{pm}$ in Manga there was a rising trend in mean relative humidity with an irregular pattern (Figure 2). Binduri showed an irregular trend at $3 \mathrm{pm}$ (Figure 4), whilst Garu showed a falling trend at $3 \mathrm{pm}$ with a sharp increase between 2006 to 2011 (Figure 6).

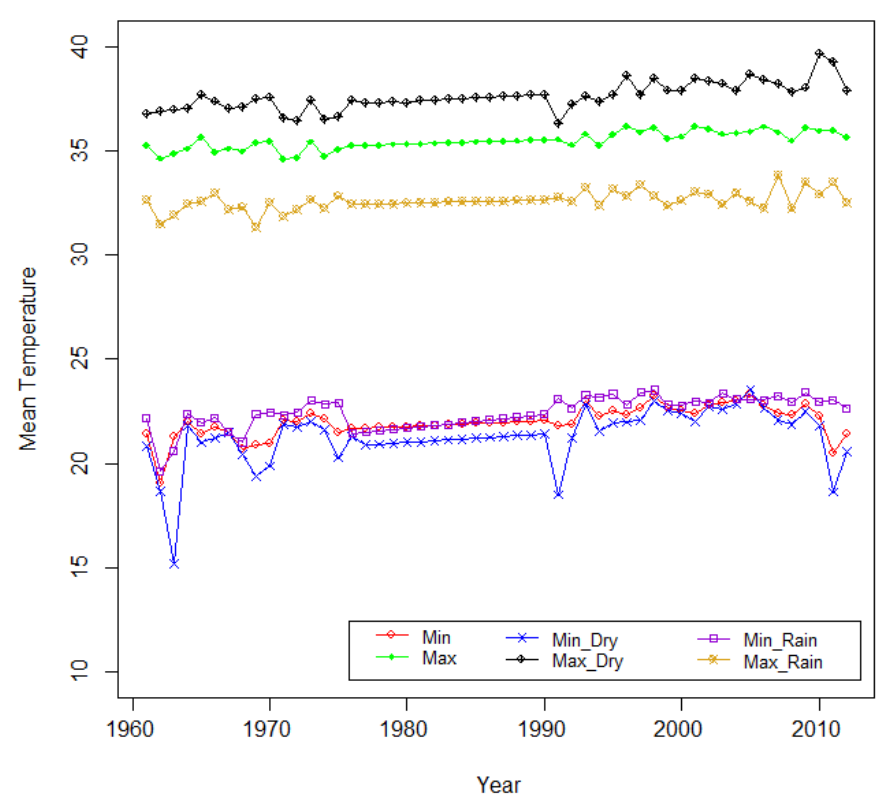

Figure 2. Seasonal and yearly trends of minimum and maximum temperatures in Manga (Bawku East). Min = Minimum mean yearly temperature; Max = Maximum mean yearly temperature; Min_Dry = Mean seasonal temperature for dry season; Max_Dry =- Mean maximum temperature in the dry season; Min_Rain = Mean seasonal temperature in the rainy season; Max_Rain = Mean Maximum temperature in the rainy season 
Table 2. Regression analysis of yearly temperature and relative humidity for Manga Bawku. $\mathrm{Mn}=\mathrm{minimum}$; $\mathrm{Mx}$ $=$ Maximum; DW $=$ Durbin Watson, $\mathrm{DS}=$ Dry season, $\mathrm{SE}=$ Standard Error

\begin{tabular}{|c|c|c|c|c|c|c|c|c|c|c|c|c|c|}
\hline \multicolumn{7}{|c|}{ Temperature } & \multicolumn{7}{|c|}{ Relative Humidity } \\
\hline variable & slope & SE & t-value & P-value & $\mathrm{R}$-square & DW & variable & slope & SE & t-value & P-value & $\mathrm{R}$-square & DW \\
\hline Mean & 0.022 & 0.002 & 9.368 & $<0.001$ & 0.637 & 1.950 & Mean & 0.083 & 0.038 & 2.188 & $<0.034$ & 0.105 & 1.641 \\
\hline \multirow[t]{2}{*}{ Mx Tem } & & & & & & & $\begin{array}{ll}\text { R.H } \quad 6\end{array}$ & & & & & & \\
\hline & & & & & & & $\mathrm{AM}$ & & & & & & \\
\hline Mean & 0.029 & 0.006 & 5.114 & $<0.001$ & 0.343 & 1.421 & Mean & 0.0205 & 0.035 & 2.188 & $<0.001$ & 0.463 & 1.333 \\
\hline Mn Tem & & & & & & & RH 3PM & & & & & & \\
\hline Mean & 0.033 & 0.004 & 7.881 & $<0.001$ & 0.554 & 1.558 & Mean & 0.136 & 0.051 & 2.674 & $<0.001$ & 0.148 & 1.889 \\
\hline Mx Tem & & & & & & & RH 6 & & & & & & \\
\hline DS & & & & & & & AM DS & & & & & & \\
\hline Mean & 0.016 & 0.003 & 4.676 & $<0.001$ & 0.304 & 2.567 & Mean & 0.048 & 0.020 & 2.389 & $<0.022$ & 0.122 & 1.551 \\
\hline MXTem & & & & & & & RH 6 & & & & & & \\
\hline RS & & & & & & & AM RS & & & & & & \\
\hline Mean & 0.041 & 0.011 & 3.655 & $<0.001$ & 0.211 & 1.47 & Mean & 0.160 & 0.037 & 4.358 & $<0.001$ & 0.317 & 1.389 \\
\hline Mn Tem & & & & & & & RH 3PM & & & & & & \\
\hline DS & & & & & & & DS & & & & & & \\
\hline Mean & 0.036 & 0.005 & 6.775 & $<0.001$ & 0.479 & 1.593 & Mean & 0.297 & 0.023 & 12.630 & $<0.001$ & 0.796 & 1.847 \\
\hline Mn Tem & & & & & & & RH 3PM & & & & & & \\
\hline RS & & & & & & & RS & & & & & & \\
\hline
\end{tabular}

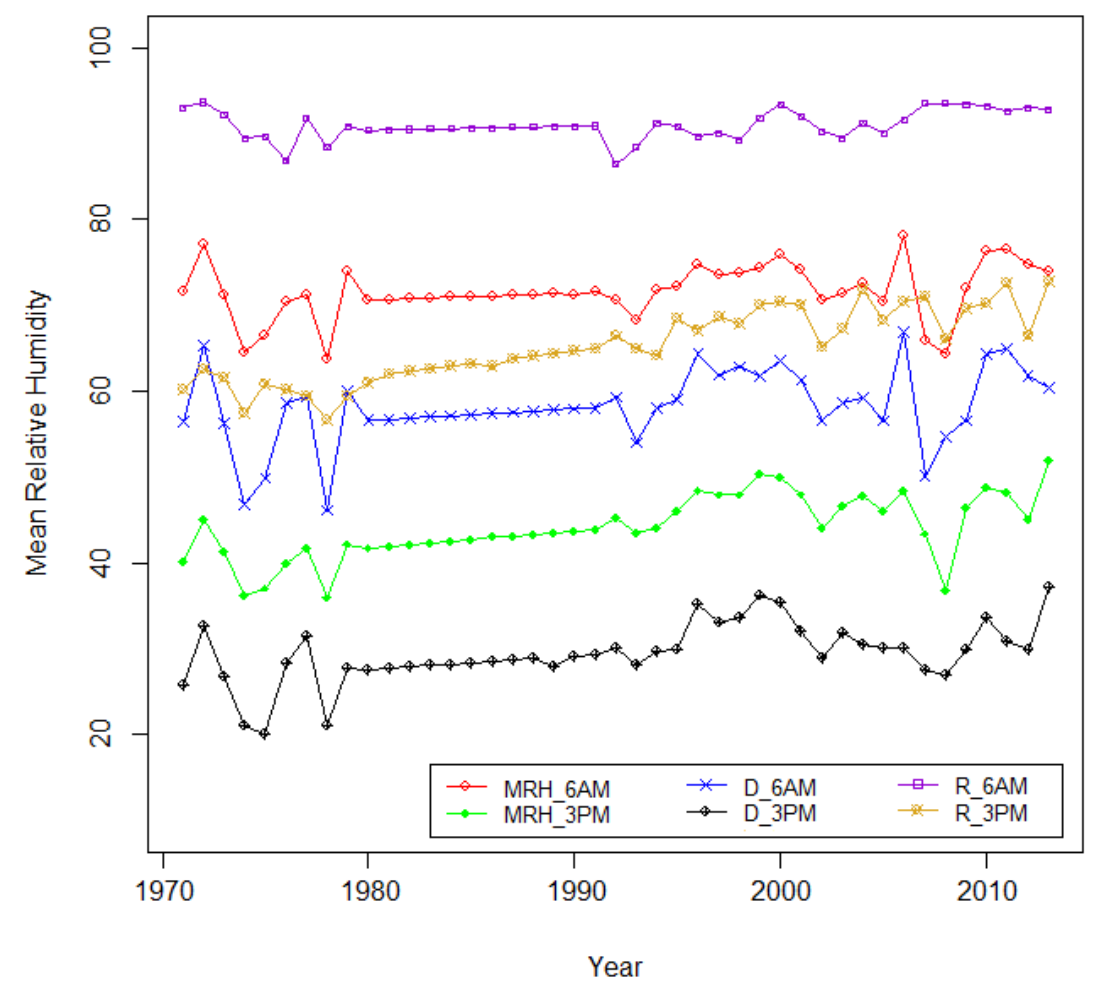

Figure 3. Seasonal and yearly trends of mean relative humidity at $6 \mathrm{AM}$ and 3PM in Manga (Bawku East). MRH_6AM = Yearly mean relative humidity at 6AM; MRH_3PM = Yearly mean relative humidity at 3PM; D_6AM = Seasonal mean relative humidity at 6AM in the dry season; D_3PM = Seasonal mean relative humidity at $3 \mathrm{PM}$ in the dry season; $\mathrm{R}_{-} 3 \mathrm{PM}=$ Seasonal mean relative humidity at $3 \mathrm{PM}$ in the rainy season 


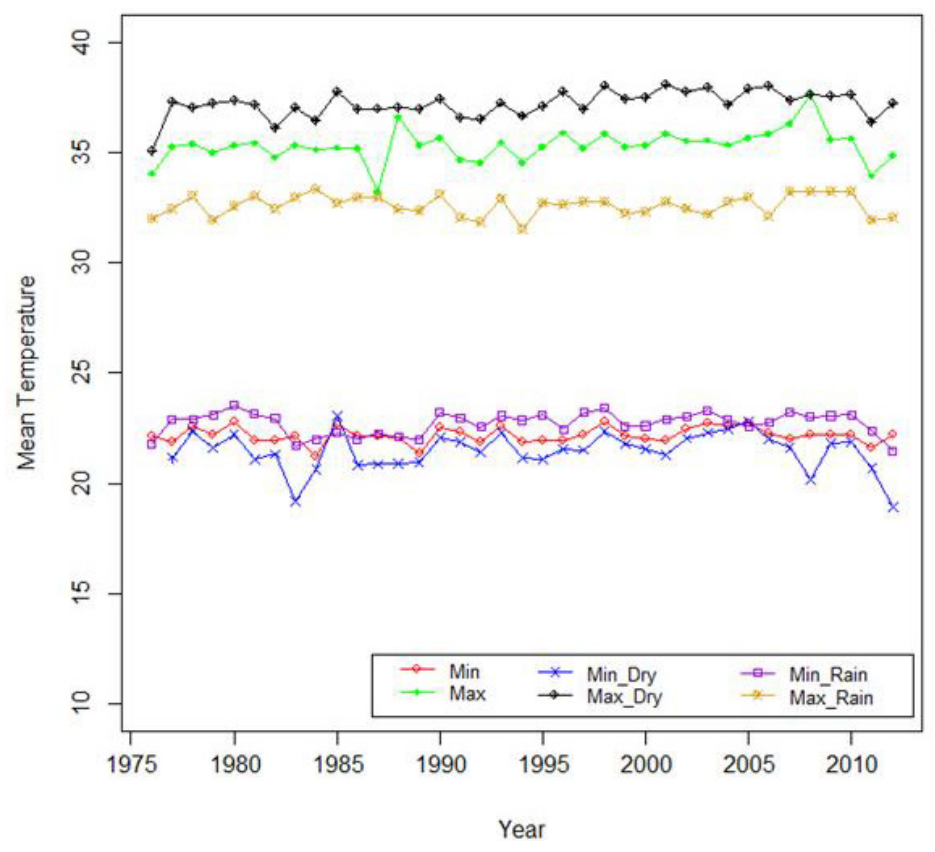

Figure 4. Seasonal and yearly trends of minimum and maximum temperatures in Binduri (Bawku East). Min $=$ Minimum mean yearly temperature; Max $=$ Maximum mean yearly temperature; Min_Dry $=$ Mean seasonal temperature for dry season; Max_Dry = Mean maximum temperature in the dry season; Min_Rain = Mean seasonal temperature in the rainy season; Max_Rain = Mean Maximum temperature in the rainy season

Table 3. Regression analysis of mean yearly temperature and mean yearly relative humidity for Binduri (Bawku East). Abbreviations as per Table 2

\begin{tabular}{|c|c|c|c|c|c|c|c|c|c|c|c|c|c|}
\hline \multicolumn{7}{|c|}{ Temperature } & \multicolumn{7}{|c|}{ Relative Humidity } \\
\hline variables & slope & SE & t-value & $\mathrm{P}$-value & $\mathrm{R}$-square & DW & variable & slope & SE & t-value & $\mathrm{P}$-value & R-square & DW \\
\hline Mean Mx & 0.021 & 0.011 & 1.876 & $<0.069$ & 0.091 & 1.923 & Mean & -0.299 & 0.188 & -1.594 & $<0.125$ & 0.104 & 1.396 \\
\hline \multirow[t]{2}{*}{ Tem } & & & & & & & $\begin{array}{ll}\text { R.H } \quad 6\end{array}$ & & & & & & \\
\hline & & & & & & & $\mathrm{AM}$ & & & & & & \\
\hline Mean Mn & 0.003 & 0.006 & 0.576 & $<0.568$ & 0.009 & 2.142 & Mean & -0.245 & 0.123 & -1.994 & $<0.059$ & 0.153 & 1.600 \\
\hline Tem & & & & & & & RH 3PM & & & & & & \\
\hline Mean $\mathrm{Mx}$ & 0.026 & 0.008 & 3.159 & $<0.003$ & 0.222 & 1.793 & Mean & -0.208 & 0.157 & -1.324 & $<0.199$ & 0.074 & 1.396 \\
\hline \multirow[t]{2}{*}{ Tem DS } & & & & & & & RH 6 & & & & & & \\
\hline & & & & & & & AM DS & & & & & & \\
\hline Mean & 0.002 & 0.007 & 0.277 & $<0.784$ & 0.002 & 1.892 & Mean & -0.523 & 0.061 & -8.606 & $<0.001$ & 0.771 & 1.470 \\
\hline MXTem & & & & & & & RH 6 & & & & & & \\
\hline RS & & & & & & & AM RS & & & & & & \\
\hline Mean Mn & 0.045 & 0.029 & 1.523 & $<0.137$ & 0.062 & 1.418 & Mean & -0.401 & 0.140 & -2.857 & $<0.001$ & 0.271 & 1.488 \\
\hline \multirow[t]{2}{*}{ Tem DS } & & & & & & & RH 3PM & & & & & & \\
\hline & & & & & & & DS & & & & & & \\
\hline Mean Mn & 0.006 & 0.008 & 0.801 & $<0.429$ & 0.018 & 1.505 & Mean & -0.053 & 0.079 & -0.671 & $<0.510$ & 0.020 & 1.655 \\
\hline \multirow[t]{2}{*}{ Tem RS } & & & & & & & RH 3PM & & & & & & \\
\hline & & & & & & & RS & & & & & & \\
\hline
\end{tabular}




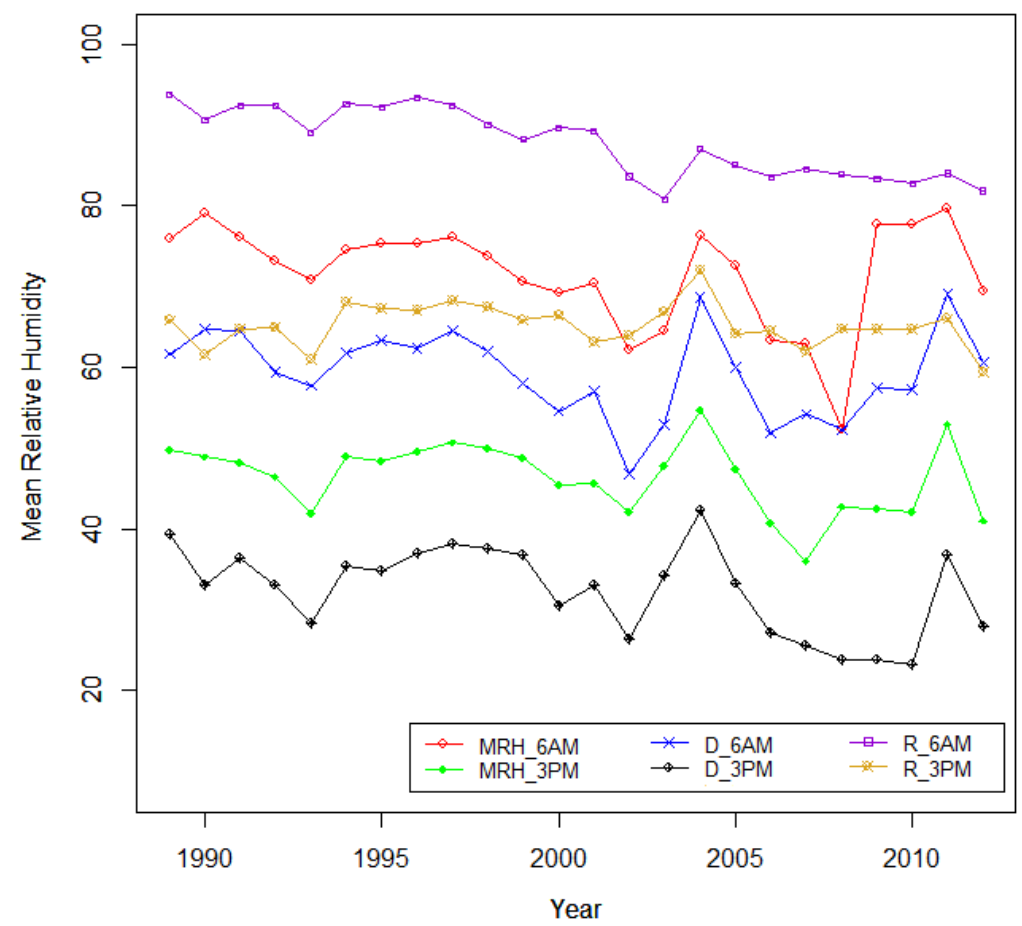

Figure 5. Seasonal and yearly trends of mean relative humidity at 6 am and $3 \mathrm{pm}$ in Binduri (Bawku East) MRH_6 am- Yearly mean relative humidity at $6 \mathrm{am}, \mathrm{MRH} \_3 \mathrm{pm}$-Yearly mean relative humidity at $3 \mathrm{pm}, \mathrm{D} \_6$ am Seasonal mean relative humidity at $6 \mathrm{am}$ in the dry season, D_3 pm- Seasonal mean relative humidity at 3 $\mathrm{pm}$ in the Dry season, R_ 3 pm Seasonal mean relative humidity at $3 \mathrm{pm}$ in the rainy season

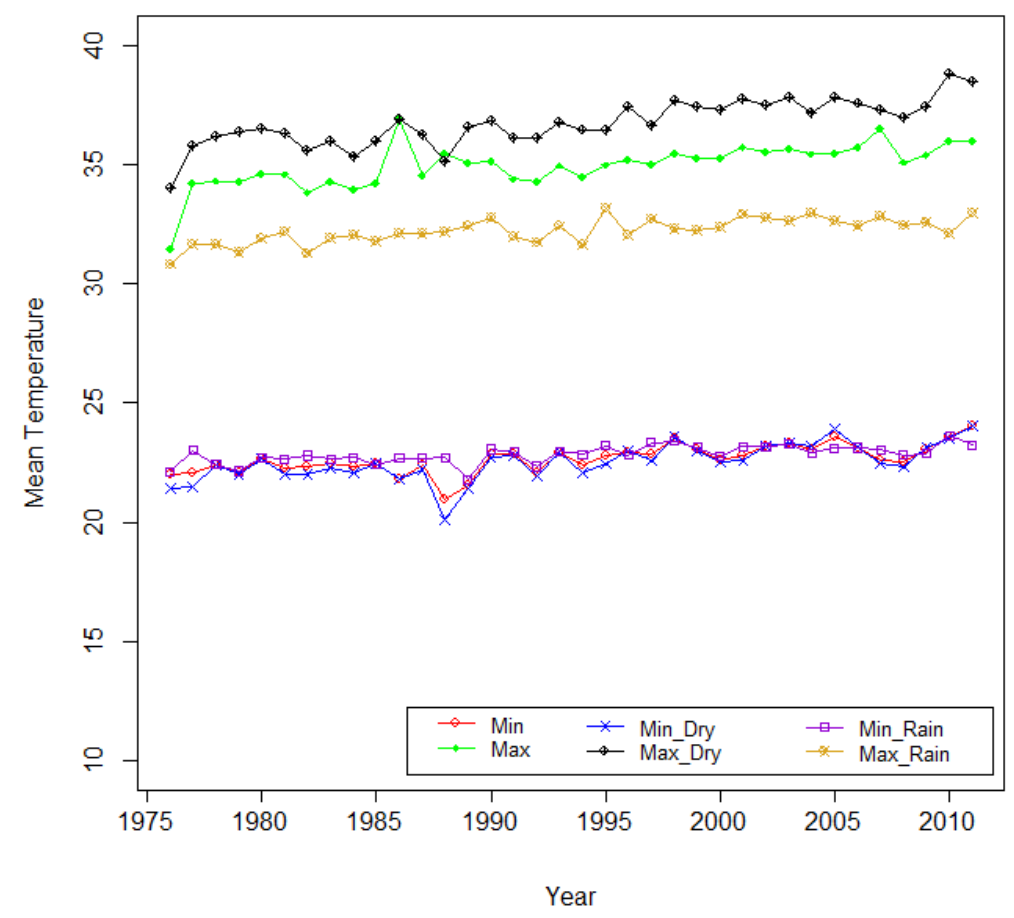

Figure 6. Seasonal and yearly trends of minimum and maximum temperatures in Garu (Bawku East). Min = Minimum mean yearly temperature; Max $=$ Maximum mean yearly temperature; Min_Dry $=$ Mean seasonal temperature for dry season; Max_Dry =- Mean maximum temperature in the dry season;, Min_Rain = Mean seasonal temperature in the rainy season; Max_Rain = Mean Maximum temperature in the rainy season 
Table 4. Regression analysis of yearly mean temperature and yearly mean relative humidity for Garu Bawku East. Abbreviations as per Table 2

\begin{tabular}{|c|c|c|c|c|c|c|c|c|c|c|c|c|c|}
\hline \multicolumn{7}{|c|}{ Temperature } & \multicolumn{7}{|c|}{ Relative Humidity } \\
\hline variables & slope & SE & t-value & P-value & R-square & DW & variable & slope & $\mathrm{SE}$ & t-value & P-value & R-square & DW \\
\hline Mean Mx & 0.060 & 0.010 & 5.789 & $<0.001$ & 0.488 & 1.698 & Mean & -0.383 & 0.118 & -3.248 & $<0.004$ & 0.334 & 1.782 \\
\hline \multirow[t]{2}{*}{ Tem } & & & & & & & R.H 6 & & & & & & \\
\hline & & & & & & & $\mathrm{AM}$ & & & & & & \\
\hline Mean Mn & 0.039 & 0.007 & 5.475 & $<0.001$ & 0.469 & 1.421 & Mean & 0.051 & 0.096 & 0.531 & $<0.600$ & 0.013 & 1.097 \\
\hline Tem & & & & & & & RH 3PM & & & & & & \\
\hline Mean Mx & 0.075 & 0.009 & 8.273 & $<0.001$ & 0.688 & 1.561 & Mean & -0.487 & 0.115 & -4.228 & $<0.001$ & 0.460 & 1.578 \\
\hline \multirow[t]{2}{*}{ Tem DS } & & & & & & & RH & & & & & & \\
\hline & & & & & & & AM DS & & & & & & \\
\hline Mean & 0.036 & 0.006 & 6.192 & $<0.001$ & 0.530 & 2.274 & Mean & -1.45 & 0.068 & -2.146 & $<0.044$ & 0.180 & 1.548 \\
\hline MXTem & & & & & & & RH 6 & & & & & & \\
\hline RS & & & & & & & AM RS & & & & & & \\
\hline Mean Mn & 0.049 & 0.009 & 5.192 & $<0.001$ & 0.442 & 1.547 & Mean & -0.169 & 0.107 & -1.580 & $<0.128$ & 0.102 & 1.530 \\
\hline \multirow[t]{2}{*}{ Tem DS } & & & & & & & RH 3PM & & & & & & \\
\hline & & & & & & & DS & & & & & & \\
\hline \multirow{3}{*}{$\begin{array}{l}\text { Mean Mn } \\
\text { Tem RS }\end{array}$} & 0.023 & 0.005 & 4.892 & $<0.001$ & 0.413 & 2.241 & Mean & 0.273 & 0.122 & 2.243 & $<0.035$ & 0.186 & 1.510 \\
\hline & & & & & & & RH 3PM & & & & & & \\
\hline & & & & & & & RS & & & & & & \\
\hline
\end{tabular}

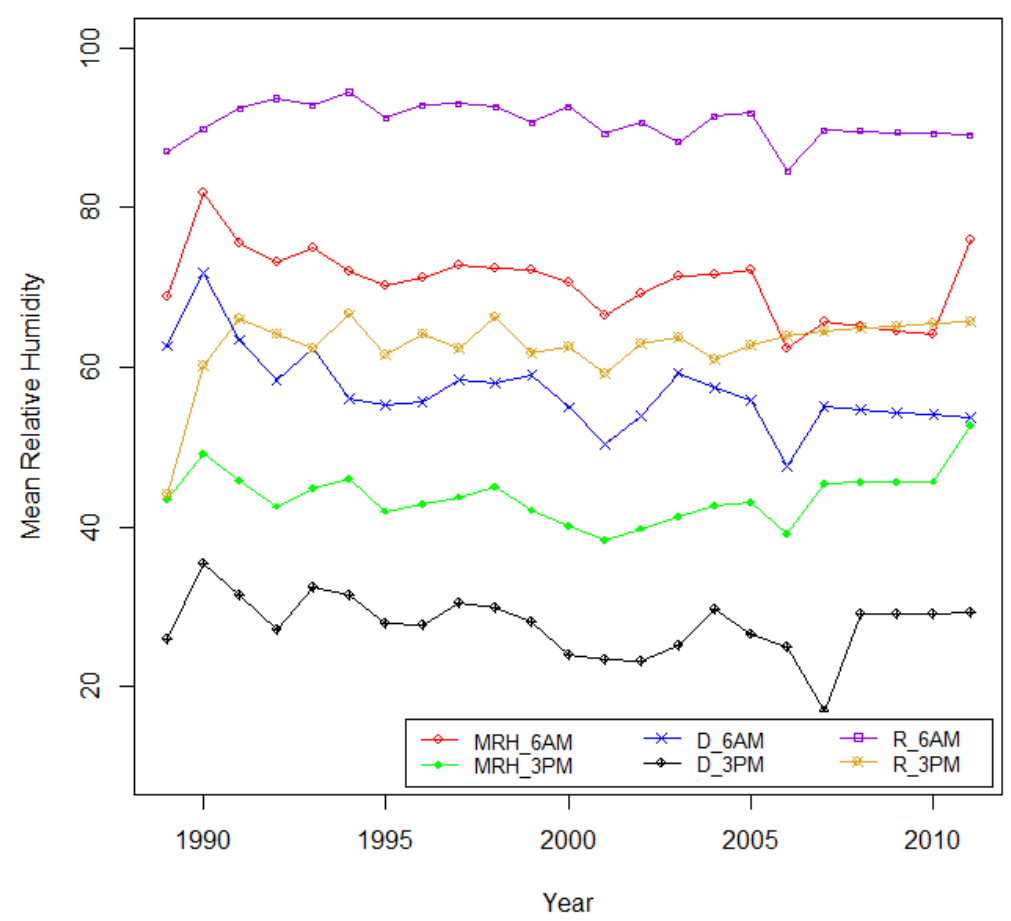

Figure 7. Seasonal and yearly trends of mean relative humidity at 6 am and 15 pm in Garu (Bawku East) MRH_6 am- Yearly mean relative humidity at 6 am, MRH_3 pm -Yearly mean relative humidity at 3 pm, D_6 am Seasonal mean relative humidity at 6 am in the dry season, D_3 pm- Seasonal mean relative humidity at $3 \mathrm{pm}$ in the Dry season, R_3 pm Seasonal mean relative humidity at $3 \mathrm{pm}$ in the rainy season

\subsection{Seasonal Trends in Temperature and Relative Humidity}

The seasonal trends that the study identified include mean annual minimum and mean annual maximum temperatures for the dry and rainy seasons, as well as the mean yearly relative humidity at 6 am and $3 \mathrm{pm}$ in the 
rainy and dry seasons. Mean minimum and mean maximum temperatures in the dry seasons in Manga showed a rising trend, with increasing pace, as illustrated in Figure 2. The mean yearly trend of maximum temperature (in Manga) in the dry season had a slope rate of $0.033{ }^{\circ} \mathrm{C}$ with a decadal increase of $0.33{ }^{\circ} \mathrm{C}$. The mean minimum yearly temperatures in the dry season had a slope of $0.041{ }^{\circ} \mathrm{C}$ with a decadal increase of $0.41{ }^{\circ} \mathrm{C}$. The mean yearly trend of maximum temperature in the rainy season had a slope of $0.016{ }^{\circ} \mathrm{C}$ with a decadal increase of $0.16{ }^{\circ} \mathrm{C}$. The mean yearly trend of minimum temperatures in the rainy season had a slope of $0.036{ }^{\circ} \mathrm{C}$ with a decadal increase of $0.36{ }^{\circ} \mathrm{C}$ (Table 2). There were similar states of rise and fall of trends of mean relative humidity at 6 am and $3 \mathrm{pm}$ in both dry and rainy seasons in Manga, as shown in Figure 3.

Table 3 showed that the mean yearly trend of maximum temperature in the dry season at Binduri had a slope rate of $0.026^{\circ} \mathrm{C}$ with a decadal increase of $0.26{ }^{\circ} \mathrm{C}$. The mean yearly trend of minimum temperature in the dry season had a slope of $0.045{ }^{\circ} \mathrm{C}$ with a decadal increase $0.45^{\circ} \mathrm{C}$. In the rainy season the mean yearly trend of maximum temperatures in Binduri had a slope of only $0.002{ }^{\circ} \mathrm{C}$ with a decadal increase of $0.02{ }^{\circ} \mathrm{C}$. The mean yearly trend of minimum temperatures in the rainy season had a slope of $0.006{ }^{\circ} \mathrm{C}$ with a decadal increase of $0.06{ }^{\circ} \mathrm{C}$. The mean yearly relative humidity in dry and rainy seasons at 6 am and $3 \mathrm{pm}$ have shown significant falling trends, as presented in Figure 5.

The mean yearly trends of minimum and maximum temperatures in Garu in rainy and dry seasons have shown significant rising trends (Table 4). In the dry season, the mean yearly trend of maximum temperature had a slope of $0.075{ }^{\circ} \mathrm{C}$ with a decadal increase of $0.75{ }^{\circ} \mathrm{C}$. The mean minimum trend of temperature in the dry season has a slope of $0.049{ }^{\circ} \mathrm{C}$ with a decadal increase of $0.49{ }^{\circ} \mathrm{C}$ (Table 4). The average yearly trend of maximum temperature in the rainy season had a slope of $0.036{ }^{\circ} \mathrm{C}$ with a decadal increase of $0.36{ }^{\circ} \mathrm{C}$. The mean yearly trend of minimum temperature in the rainy season had a slope of 0.023 and a decadal increase of $0.23{ }^{\circ} \mathrm{C}$. There were significant falling trends in all the mean yearly relative humidity at $6 \mathrm{am}, 3 \mathrm{pm}$, in both rainy and dry seasons (Figure 7).

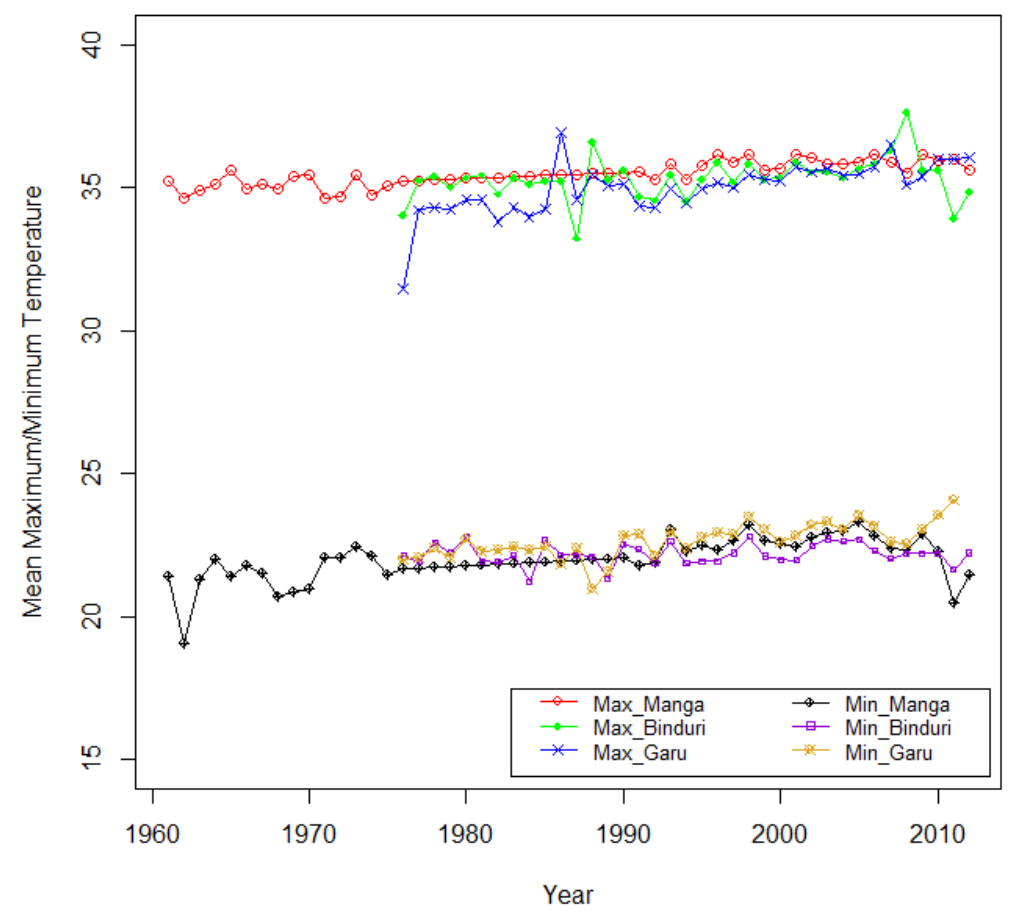

Figure 8. Yearly trends of mean maximum and mean minimum temperatures in Manga, Binduri and Garu

\section{Discussion and Conclusion}

In the time frame from 1961-2012, in Bawku East of northern Ghana, Garu recorded a significant rise in mean temperatures above the national annual average of $0.027^{\circ} \mathrm{C}$ per year. The greatest rate of increase was in the dry season with mean annual temperature rise of $0.075{ }^{\circ} \mathrm{C}$ and a decadal increase of $0.75{ }^{\circ} \mathrm{C}$ (Table 4). In all, there were a greater increase in temperature in Garu, than Manga and Binduri. Although having a lower rise in temperatures compared to Binduri, Manga also recorded a significant rise in temperature. Mean minimum 
temperatures in the dry season sustained a significant surge at Manga, followed by mean annual dry season temperature and mean annual temperature. Other temperature trends were not significant.

In Ghana there had been a reported annual temperature rise of $0.021{ }^{\circ} \mathrm{C}$ in the south (which translates to a decadal increase of $0.21{ }^{\circ} \mathrm{C}$ ) and $0.027{ }^{\circ} \mathrm{C}$ in northern Ghana (McSweeney, 2012), which conforms with results of this study. Since 1960 and up to 2012, there has been a rise of $1 \mathrm{oC}$ of temperature throughout the country with northern Ghana experiencing a rapid increase than the south, although other parts of northern Ghana have higher rates of increase than the overall average (McSweeney, 2012). The Environmental Protection Agency of Ghana has predicted that northern Ghana will experience a temperature surge of $2.5-3{ }^{\circ} \mathrm{C}$ by the year 2020 (EPA, 2007). Depending on climate change and its consequential effect on temperature, Bawku East is likely to have an additional surge of $1-1.5^{\circ} \mathrm{C}$ of temperature if the pace of increase in temperature in Garu is sustained. This will be close to the prediction of the Ghana environmental protection agency (EPA, 2007).

In Garu, the humidity has fallen as temperatures have risen. In Manga, there were rising and falling trends with regard to relative humidity which failed to present a clear pattern. In Binduri, relative humidity showed a rise and fall pattern. In each case, the combination of high temperature and humidity is inimical to human health especially on people who work outside. A study in Abu Dhabi and Syria stipulated that the integration of temperature and humidity was responsible for reported cases of increased heat stroke (Shanks \& Papworth, 2001; Zawahri, 2004). There was a proliferation of heat cramps detected among people who work outside in Kuwait due to a combination of high temperature and humidity (Al-Ahwal, Norman, \& Brebner, 2000). Both low and high air humidity when combined with high temperature have health effects for a given population. A combination of high temperature and low humidity have been assessed to be one of the causes of kidney failures (Al-Tawheed et al., 2003). Studies indicate that high temperature with low humidity in an outdoor working environment has the tendency to cause acute meningitis (Shaikh, Shaikh, \& Faiz, 2003), kidney stones (Khan, 1991) and congenital hypothyroidism (Hashemipour et al., 2007).

Even though there has been an increase in average surface temperatures of the globe, the trend varies across continents and in local contexts (IPCC, 2007a). For instance, in an extensive analysis of temperature trends in Limpopo province of South Africa, trends in temperature over a 50 -year period were found not to be uniform throughout the province, though the study confirmed that there had been an upsurge in average yearly temperatures in each station (Tshiala, Olwoch, \& Engelbrecht, 2011).

This study has shown that hotness in a predominantly hot environment is being exacerbated by global climate change with more temperatures above critical levels. The number of days and months per year where temperatures exceeded such stressful conditions also increased over the last 50 years. For instance, between 1961-75 at Manga, an average of 2.3 months per year had mean temperatures greater than $37{ }^{\circ} \mathrm{C}$, which had increased to 5.3 months per year between 1998-2012.

A large number of hot environments (temperatures regularly beyond $37{ }^{\circ} \mathrm{C}$ ) will have a $1-2{ }^{\circ} \mathrm{C}$ increase in average temperature within this century, and beyond this temperature in such environments is likely to increase by another $2-4{ }^{\circ} \mathrm{C}$ (IPCC, 2007b). Physical activities such as weeding, digging holes and other farming activities in hot environments induce heat internally that can be difficult to dissipate when air relative humidity is high (Kjellstrom, 2009). When there are inadequate cooling methods in hot outdoor working environments with workers wearing light clothing, taking breaks is the only way for a worker to reduce the effects of heat stress. However, such breaks could undermine the hourly work rate with consequential impact on economic productivity (Parsons, 2003). Even though the air relative humidity has decreased slightly, such levels still make outdoor work uncomfortable by reducing the mechanism of the body to dissipate heat.

The risk to human health imposed by high temperatures, especially for farmers, and other outdoor workers in Bawku East and other heat-prone environments in northern Ghana, warrant the need for policies and programmes to curb the heat stress impact on outdoor workers. There is the need by government to develop occupational health programmes specifically aimed at heat stress in northern Ghana. It is essential that farmers need to be supported to alleviate food insecurity and maintain sustainable agriculture in the region. Proper adaptation mechanisms need to be instituted since studies indicate that rural livelihood will be largely affected by health impacts of climate change and increases in temperature (Midgley et al., 2007)

In many parts of the world there are no data on temperature available for analysis of temporal trends (Frich et al., 2002). Meteorological data on climate and temperature are scarce in many parts of the developing world, including Africa (Caesar, Alexander, \& Vose, 2006). Civil war, political instability, and scientific and technological inadequacy in many African countries have aggravated the problem of getting adequate climate information (McCarthy, 2001). On average, it is estimated that there is one weather station per $26000 \mathrm{~km}^{2}$ in the 
African region, which is 8 times below the minimum level recommended by the World Meteorological Organization. Moreover, the spread of these stations is uneven. There are no up to date climatic records in many stations in Africa (Washington, Harrison, Conway, \& Black, 2004).

Some studies indicate that the upward trend of temperature apparent from smaller scale analysis and simulation is difficult to attribute to anthropogenic causes rather than to natural variability (Hegerl et al., 2007). Even though this paper considers recent trends and levels of temperature and relative humidity, planned future study will measure human exposure to heat by taking into account local measurements of temperature and relative humidity every hour in a variety of settings (e.g., indoor and outdoor, shaded and full sun). This will reveal the extent of heat exposure on outdoor workers, specifically farmers, across the day during their pursuit to achieve sustainable farming, as well as during the night and during other resting times.

Assessment of local heat exposure on a daily and monthly basis with heat measuring equipment in Bawku East and other parts of northern Ghana is timely and appropriate since it can help determine appropriate remedial action. Such actions include adaptation to reduce the impact of heat exposures like air conditioning or fans in the home, appropriate shade at the farm level to minimise heat impact and use of mechanised farming instead of human physical labour. This can help outdoor workers such as farmers to adapt to both current and future level of heat and climate change.

\section{Acknowledgement}

The authors wish to acknowledge Ghana Meteorological Agency for supplying the data for the study. The School of Natural Sciences, Edith Cowan University, Perth, Australia is greatly acknowledged for the funding support for the study.

\section{References}

Al-Ahwal, S. H., Norman, J. N., \& Brebner, J. A. (2000). Heat cramps in a hot desert work-site. Kuwait Medical Journal, 32(4), 382-386.

Al-Tawheed, A. R., Al-Awadi, K. A., Kehinde, E. O., Abdul-Halim, H., Al-Hunayan, A., Ali, Y., \& Mohammed, A. H. (2003). Anuria secondary to hot weather-induced hyperuricaemia: diagnosis and management. Ann Saudi Med, 23(5), 283-7.

Anayah, F., \& Kaluarachchi, J. J. (2009). Groundwater resources of northern Ghana: Initial assessment of data availability. Utah State UniversityLogan, USA.

Appiah, K. S. (2014). Space-time statistical analysis of malaria morbidity incidence cases in Ghana: A geostatistical modelling approach (PhD Monograph). Edith Cowan University, Perth.

Arora, M., Goel, N. K., \& Singh, P. (2005). Evaluation of temperature trends over India/Evaluation de tendances de température en Inde. Hydrological sciences journal, 50(1). http://dx.doi.org/10.1623/hysj.50.1.81.56330

Brown, S. J., Caesar, J., \& Ferro, C. A. (2008). Global changes in extreme daily temperature since 1950. Journal of Geophysical Research: Atmospheres (1984-2012), 113(D5).

Byass, P., Twine, W., Collinson, M., Tollman, S., \& Kjellstrom, T. (2010). Assessing a population's exposure to heat and humidity: an empirical approach. Global health action, 3.

Caesar, J., Alexander, L., \& Vose, R. (2006). Large-scale changes in observed daily maximum and minimum temperatures: Creation and analysis of a new gridded data set. Journal of Geophysical Research: Atmospheres (1984-2012), 111(D5).

Cane, M. A., Clement, A. C., Kaplan, A., Kushnir, Y., Pozdnyakov, D., Seager, R., ... Murtugudde, R. (1997). Twentieth-century sea surface temperature trends. Science, 275(5302), 957-960. http://dx.doi.org/10.1126/science.275.5302.957

Christensen, J., Hewitson, B. C., Busuioc, A., Chen, A., Gao, X., \& Jones, R. (2007). Climate Change 2007: The scientific Basis. Regional Climate Projections in IPCC fourth Assessment Report. Cambridge: Cambridge University Press.

Collins, J. M. (2011). Temperature Variability over Africa. Journal of climate, 24(14). http://dx.doi.org/10.1175/2011JCLI3753.1

Easterling, D. R., Horton, B., Jones, P. D., Peterson, T. C., Karl, T. R., Parker, D. E., ... Folland, C. K. (1997). Maximum and minimum temperature trends for the globe. Science, 277(5324), 364-367. http://dx.doi.org/10.1126/science.277.5324.364 
EPA. (2007). Climate Change and Ghanian Economy (Vol. 1). Accra: Environmental Protection Agency of Ghana.

Fosu-Mensah, B. Y., Vlek, P. L., \& MacCarthy, D. S. (2012). Farmers' perception and adaptation to climate change: a case study of Sekyedumase district in Ghana. Environment, Development and Sustainability, 14(4), 495-505. http://dx.doi.org/10.1007/s10668-012-9339-7

Frich, P., Alexander, L. V., Della-Marta, P., Gleason, B., Haylock, M., Klein Tank, A. M., \& Peterson, T. (2002). Observed coherent changes in climatic extremes during the second half of the twentieth century. Climate Research, 19(3), 193-212. http://dx.doi.org/10.3354/cr019193

Glantz, M. H. (1992). Global warming and environmental change in sub-Saharan Africa. Global environmental change, 2(3), 183-204. http://dx.doi.org/10.1016/0959-3780(92)90002-O

Government of Ghana Offial Porter. (2014). About Ghana, Regions and districts. Retrieved from http://www.ghana.gov.gh/index.php/about-ghana/regions/upper-east

Hashemipour, M., Amini, M., Kelishadi, R., Hovsepian, S., Haghighi, S., Hosseini, M., \& Talaei, M. (2007). Seasonal variation in the incidence of congenital hypothyroidism in Isfahan, Iran. Saudi medical journal, 28(10), 1582-1586.

Hegerl, G., Zwiers, F., Braconnot, P., Gillet, N., Luo, Y., Marengo, J., ... Stott, P. (2007). Understanding and attributing climate change.

Helms, T. C., Deckard, E. L., Goos, R. J., \& Enz, J. W. (1996). Soil moisture, temperature, and drying influence $\begin{array}{llll}\text { on soybean emergence. } & \text { Agronomy journal, }\end{array}$ http://dx.doi.org/10.2134/agronj1996.00021962008800040027x

Hulme, M. (1996). Climate change within the period of meteorological records (pp. 88-102). UK: Oxford University Press Oxford.

IPCC. (2007a). Climate change 2007: impacts, adaptation and vulnerability: contribution of working group two to fourth assessment report of the IPCC. UK: Cambridge University Press.

IPCC. (2007b). Climate Change 2007: The physical Science Basis. Contribution of working Group 1 to fourth assessment report of the intergovernmental Panel on Climate Change. UK: Cambridge University Press.

Jones, P. D., Trenberth, K. E., Ambenje, P., Bojariu, R., Easterling, D., Klein, T., ... Zhai, P. (2007). Observations: surface and atmospheric climate change. In Climate Change 2007: The Physical Science Basis. Contribution of Working Group I to the Fourth Assessment Report of the Intergovernmental Panel on Climate Change, 235-336.

Kalumba, A. M., Olwoch, J. M., van Aardt, I., Botai, O. J., Tsela, P., Nsubuga, F. W. N., \& Adeola, A. M. (2013). Trend Analysis of Climate Variability over the West Bank-East London Area, South Africa (1975-2011). Journal of Geography and Geology, 5(4). http://dx.doi.org/10.5539/jgg.v5n4p131

Karl, T. R., Jones, P. D., Knight, R. W., Kukla, G., Plummer, N., Razuvayev, V., ... Peterson, T. C. (1993). Asymmetric trends of daily maximum and minimum temperature. Papers in Natural Resources, 185.

Khan, S. (1991). Hot climate and Kidney stones. Journal of Pakistan Institute of Medical Sciences, 1(2), 98.

Kjellström, T. (2009). Climate Change Exposures, Chronic Diseases, and Mental Health in Urban Populations: A Threat to Health Security, Particularly for the Poor and Disadvantaged: Technical Report. World Health Organization, Centre for Health Development.

Kruger, A. C., \& Shongwe, S. (2004). Temperature trends in South Africa: 1960-2003. International Journal of Climatology, 24(15), 1929-1945. http://dx.doi.org/10.1002/joc.1096

Laube, W., Schraven, B., \& Awo, M. (2012). Smallholder adaptation to climate change: dynamics and limits in Northern Ghana. Climatic change, 111(3-4), 753-774. http://dx.doi.org/10.1007/s10584-011-0199-1

McCarthy, J. J. (Ed.). (2001). Climate change 2001: impacts, adaptation, and vulnerability: contribution of Working Group II to the third assessment report of the Intergovernmental Panel on Climate Change. Cambridge University Press.

McSweeney, C., New, M., \& Lizcano, G. (2012). UNDP Climate Change Profiles: Ghana. UNDP.

Midgley, G. F., Chapman, R. A., Mukheibir, P., Tadross, M., Hewitson, B., Wand, S., ... Warburton, M. (2007). Impacts, vulnerability and adaptation in key South African sectors: An input into the Long Term Mitigation Scenarios process, LTMS Input Report 5. Energy Research Centre, Cape Town. 
Ministry of Agriculture, Ghana. (2012). Bawku Municipality, Physical and Natural Environment. Retrieved from http://mofa.gov.gh/site/?page_id=1642

Ministry of Food and Agriculture. (2014). Physical and Natural Environment, Bawku Municipality. Retrieved from http://mofa.gov.gh/site/?page_id=1642

Mote, P. W. (2003). Trends in temperature and precipitation in the Pacific Northwest during the twentieth century.

Pachauri, R. K. (2007). Climate Change 2007: Synthesis Report. Contribution of Working Groups I, II and III to the Fourth Assessment Report of the Intergovernmental Panel on Climate Change (Vol. 446). IPCC.

Parsons, K. C. (2003). Human thermal environments: the effect of hot, moderate and cold environments on human health, comfort and performance. Taylor \& Francis, New York.

Pascual, M., Ahumada, J. A., Chaves, L. F., Rodo, X., \& Bouma, M. (2006). Malaria resurgence in the East African highlands: temperature trends revisited. Proceedings of the National Academy of Sciences, 103(15), 5829-5834. http://dx.doi.org/10.1073/pnas.0508929103

Shaikh, S. U., Shaikh, R. B., \& Faiz, M. S. (2003). Seasonal paradox in acute meningitis at Nawabshah. Journal of the College of Physicians and Surgeons--Pakistan: JCPSP, 13(4), 207-209.

Shanks, N. J., \& Papworth, G. (2001). Environmental factors and heatstroke. Occupational Medicine, 51(1), 45-49. http://dx.doi.org/10.1093/occmed/51.1.45

Sherwood, S. C., \& Huber, M. (2010). An adaptability limit to climate change due to heat stress. Proceedings of the National Academy of Sciences, 107(21), 9552-9555. http://dx.doi.org/10.1073/pnas.0913352107

Shrestha, A. B., Wake, C. P., Mayewski, P. A., \& Dibb, J. E. (1999). Maximum Temperature Trends in the Himalaya and Its Vicinity: An Analysis Based on Temperature Records from Nepal for the Period 1971--94. Journal of climate, 12(9). http://dx.doi.org/10.1175/1520-0442(1999)012<2775:MTTITH >2.0.CO;2

Tshiala, M. F., Olwoch, J. M., \& Engelbrecht, F. A. (2011). Analysis of Temperature Trends over Limpopo Province, South Africa. Journal of Geography and Geology, 3(1). http://dx.doi.org/10.5539/jgg.v3n1p13

Vose, R. S., Easterling, D. R., \& Gleason, B. (2005). Maximum and minimum temperature trends for the globe: An update through 2004. Geophysical Research Letters, 32(23). http://dx.doi.org/10.1029/2005GL024379

Washington, R., Harrison, M., Conway, D., \& Black, E. (2004). African climate report: a report commissioned by the UK Government to review African climate science, policy and options for action. Department for Environment, Food and Rural Affairs.

Webber, P. (1996). Agrarian change in Kusasi, north-east Ghana. Africa, 66(03), 437-457. http://dx.doi.org/10.2307/1160961

Whitehead, A. (2006). Persistent poverty in north east Ghana. The Journal of Development Studies, 42(2), 278-300. http://dx.doi.org/10.1080/00220380500405410

Zawahri, M. Z. (2004). Stroke and the weather. Neurosciences, 9(1), 60-61.

\section{Copyrights}

Copyright for this article is retained by the author(s), with first publication rights granted to the journal.

This is an open-access article distributed under the terms and conditions of the Creative Commons Attribution license (http://creativecommons.org/licenses/by/3.0/). 